\title{
Mushaf - \\ Islamisk bogkunst set gennem de orientalske samlinger på Det Kongelige Bibliotek
}

afforskningsbibliotekar Bent Lerbak Pedersen

I modsætning til mange andre steder i verden fortsatte man i den islamiske verden med at skrive bøger $\mathrm{i}$ hånden helt op til 1800-tallet. Det vil sige at den islamiske bog udviklede sig med håndskrevne sider og ikke som en trykt bog. Man lagde megen vægt på den kalligrafiske udformning, og den var vanskelig at overføre til datidens trykkerimetoder. I denne artikel forstås den islamiske verden som Mellemøsten, Nordafrika, det islamiske Spanien (756-1492), Tyrkiet, Iran, det nuværende Pakistan, Nordindien og det islamiske Centralasien.

Teksten i den islamiske bog skrives fra højre mod venstre, således at siderne i bogen bliver åbnet mod højre modsat praksis i Vesten. Forsatsbladet er ofte ubeskrevet (til venstre i bogen), men kan have ejermærker - ex-libris. På næste side (til højre i bogen) begynder bogens tekst. Her kan titlen ses i stor skrift, og den er ofte i en dekorativ udførelse. Desuden kan titlen være omgivet af ornamenter, der enten kan være i meget skønne udformninger eller i mere beskedne udførelser. Ornamenterne ligner de geometriske mønstre eller plantemønster, man kan se på islamiske tæpper. Undertiden vil den centrale del i midten være udsmykket med en kuppellignende figur, der kan minde om den central kuppel på en moské.

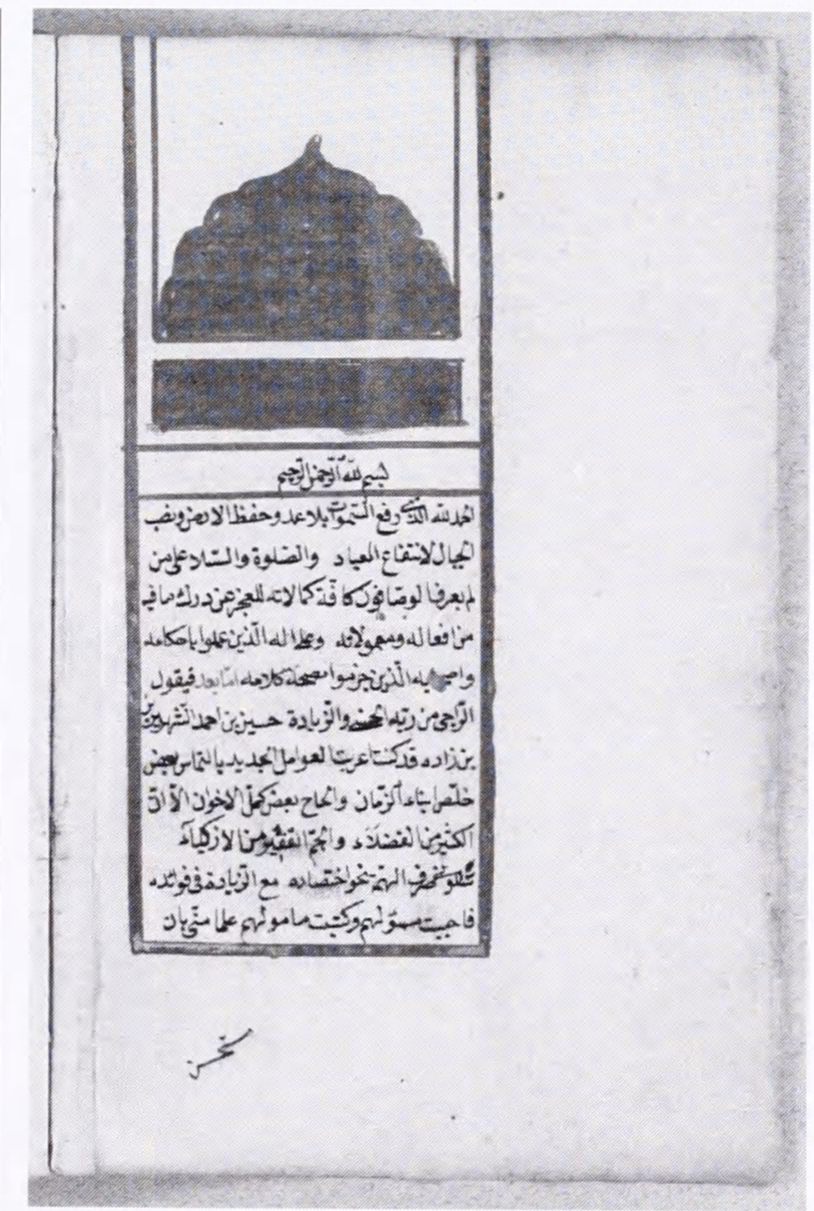

Fig 1 Titelblad til en arabisk grammatik $i$ håndskrift, nedskrevet 1780 (Det Kongelige Bibliotek).

Nogle bøger kan have indsat to sider mellem forsatsbladet og tekstens begyndelse. Disse sider er dekorerede, og de kan være meget fine og detaljerede i deres udformninger, hvilket man især ser, når det drejer sig om Koranen. 


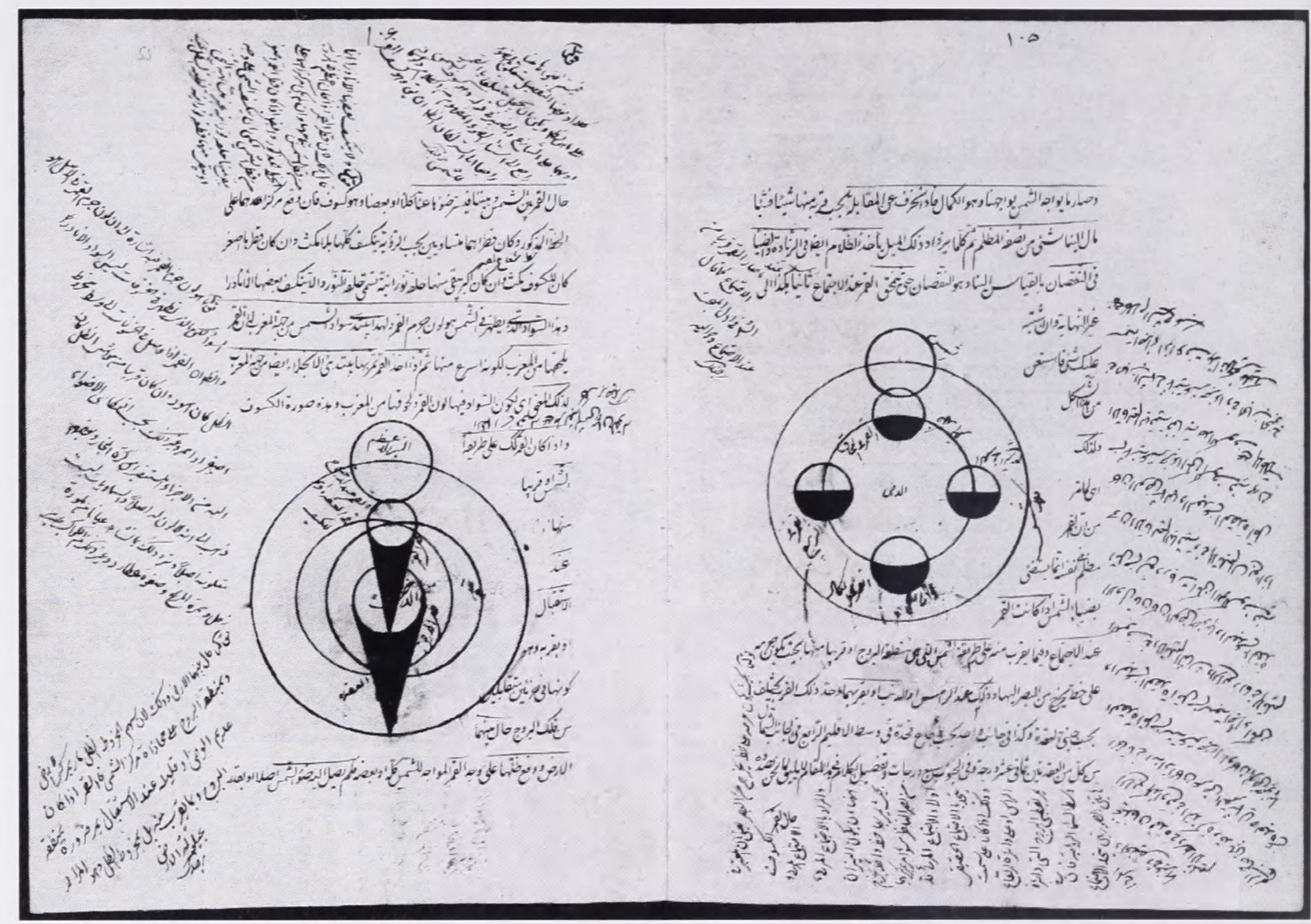

Fig. 2 Randnoterne ses her skrevet uden om selve teksten, der en i rektangular form med illustrationer. To sider fra Sarh al-Đigmini (Kommentarer til al-Đigmîni) skrevet af Qâdîzâde (d. 1412 eller 1436). Teksten i marginen er: Al-Hâðiyah ala šarh mulahhas al-Đigmîni liQâdìzâde (Forklaring til Qâdîzâdes kommentar til al-Đigmîni) skrevet af al-Birdandî̀ (d. efter 1528). Dette händskrift stammer fra 1800-tallet (Det Kongelige Bibliotek).

Teksten i alle islamiske bøger begynder med velsignelser, og den første er altid: Bism Allah al-rahman al-rahim ( I Guds navn den velgørende og barmhjærtige). De efterfølgende velsignelser kan være af forskellig længde. Når forfatteren er færdig med dem skriver han: 'og så' ... Denne erklæring er tit fremhævet - enten i form større bogstaver eller skrevet i rødt. Herefter kommer forfatteren med en slags indledning om behovet for bogen, indsamlingen af materialet og ordningen af dette. Og så kommer igen en erklæring: 'og så kalder jeg bogen' ... (her står så bogens titel). Dernæst kommer undertiden en kort beskrivelse af kapitlerne.
Mange af de islamiske bøger indeholder randnoter. Det kan være korte huskelignende noter, sammenlignende noter eller det kan være udførlige kommentarer til selve teksten. Disse lange noter omringer så selve teksten, så en tekstside kan blive helt overskrevet.

I nogle tilfælde er der i tidens løb yderligere kommet en eller to fyldige kommentarer til, så der i de senere kopieringer af bogen er indføjet de nye kommentarer uden om den oprindelige kommentar. En del af de kortere noter kan være skrevet i en ornamental form, hvor notens tekst udformes som en figur f.eks. et træ. 


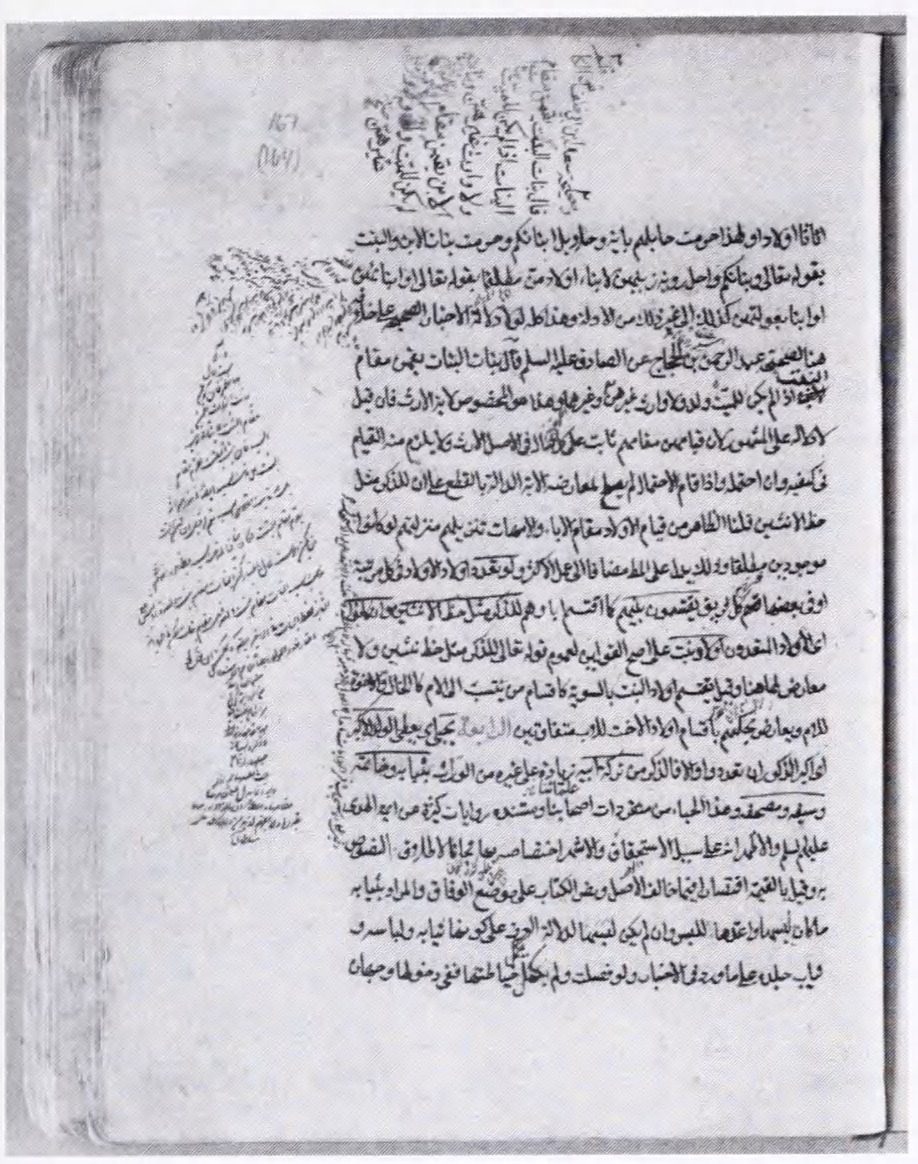

Fig. 3. Side fra handskriftet al Rawdah al-bahîyah fì Jarh alLum'ah al-dimaðqîyah (Shi'a love) af Zayn al-Dîn 'Alî ibn Ahmad alĐâmî al-'Âmilì (d. 966 H [1599]. Håndskriftet er nedskrevet sen 1600tallet eller tidlig 1700-tallet (Det Kongelige Bibliotek).

Fig. 4. Kolofon fra en kommentar til en klassisk grammatikbog. Kommentaren er fra tidlig 1700-tallet og dette eksemplar er nedskrevet i 1780 (Det Kongelige Bibliotek).

Disse figurformer kan som regel ikke relateres til bogens tekst. Det menes af brugen af randnoter stammer fra rettelser af de håndskrevne tekster, hvor udeladte ord eller rettelser af fejlskrevne ord ses i margen. Dette kan meget vel have inspireret til nedfældning af noter i margen ved side af den relevante del af teksten.

Efter afslutningen af bogens teksten kommer en kolofon, der ofte skrives med kortere og kortere tekstlinier for at ende i en spids. Man kan sige at teksten løber ud i sandet, der er intet mere at tilføje. I selve kolofonen kommer nogle vigtige oplysninger om kopisten, dateringen og stedet for nedskrivningen af teksten. I nogle bøger er denne afslutning af den nedad pegende trekant yderligere understreget med kantstreger.

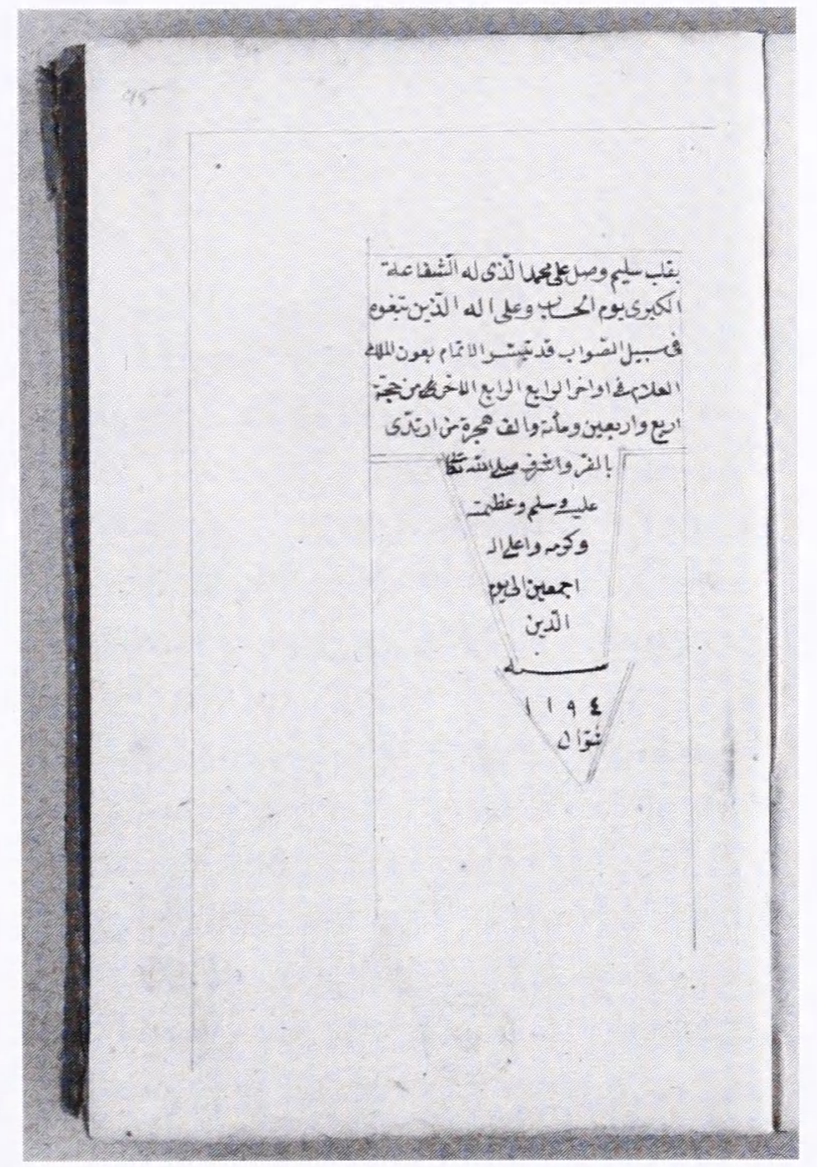




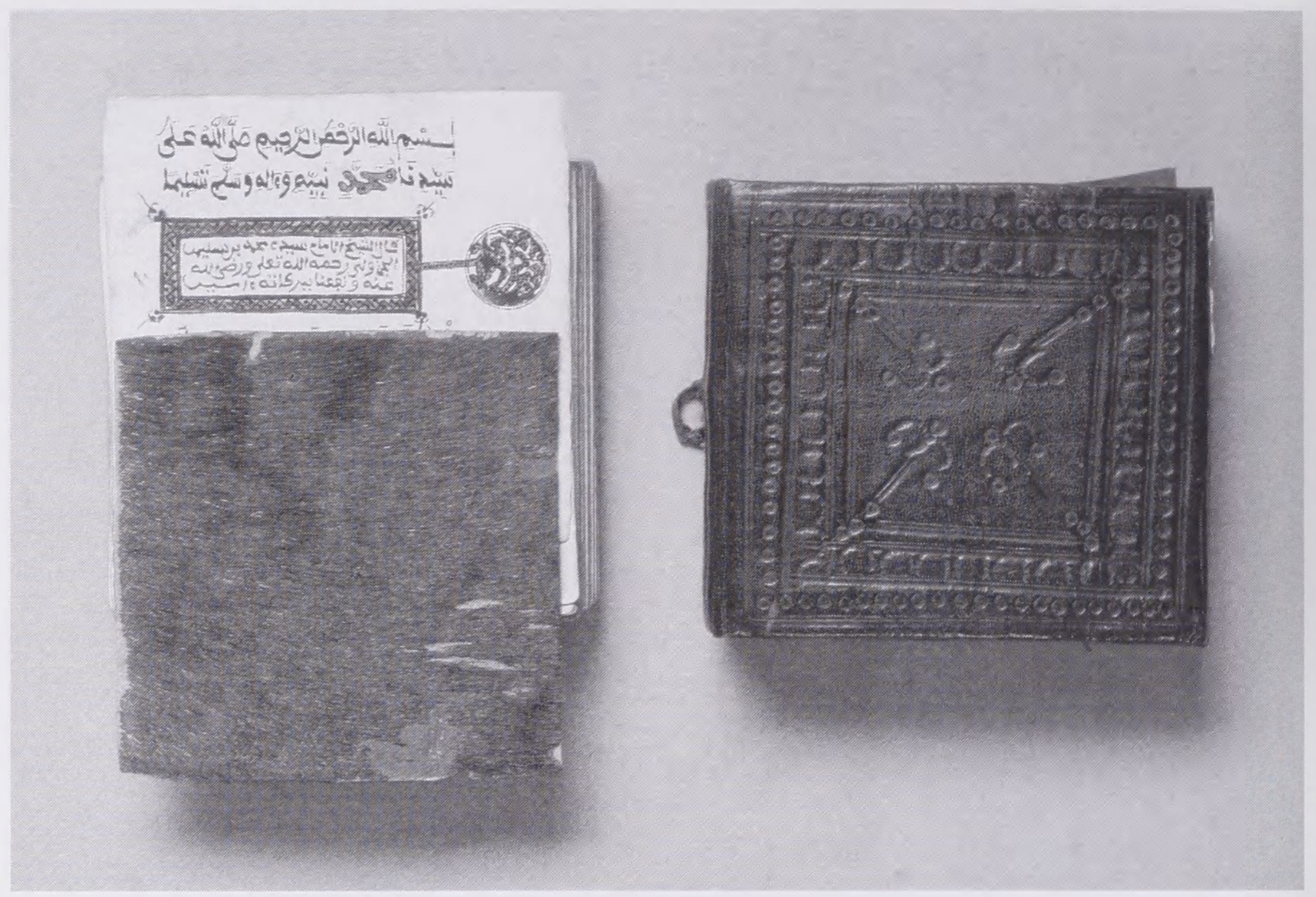

Fig. 5. Afrikansk Koran fra 1700-tallet bestående af lose blade. Øverst og nederst er det anbragt en plade af skind til beskyttelse af bladstablen. Til hojre ses et laderomslag til hele varket. Dette eksemplar minder meget om de tidlige Korantekster på pergament (Det Kongelige Bibliotek).

\section{Begyndelsen}

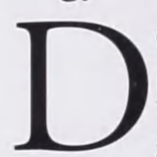
en islamiske bog opstod med behovet for at udbrede Koranen og at fastholde islamisk lærdom alle rede i midten 700 -tallet. Den tredje islamiske kalif 'Uthmân (23/644-35/656) beordrede Koranen nedskrevet, da den synes op til hans tid kun at have være overleveret i mundtlig form og med få fragmenter i skreven form. Koranen blev sandsynligvis skrevet på pergament, $\mathrm{da}$ papir ikke var kendt $\mathrm{i}$ den arabiske verden på dette tidspunkt. Den blev formodentlig heller ikke skrevet på papyrus, da dette skrivemateriale blev fremstillet $\mathrm{i}$ et så fjernt sted som Egypten. Senere ser man dog få bøger skrevet på papyrus, som især blev anvendt til administrationsdokumenter før papiret kom til den vestlige del af den arabiske verden i 800-tallet - tidlig 900-tal.

Fra skrevne kilder fra 600-tallet og fra bøger fra 7-800-tallet. vides at de tidligste Koraner blev skrevet på relativ store pergamentark af ens størrelse. Hvert udfyldt ark blev lagt oven på hinanden og alle arkene i den færdige korantekst anbragtes mellem to dækplader, der formodentlig var af træ.

Dækplader af træ har den store fordel frem for sammenlimede papyrusark eller papirark, at de beskytter pergamentarkene godt mod buler forårsaget af fugtighed, da træ er stabilt og tungt. Desuden værnes indholdet mod beskadigelse fra 


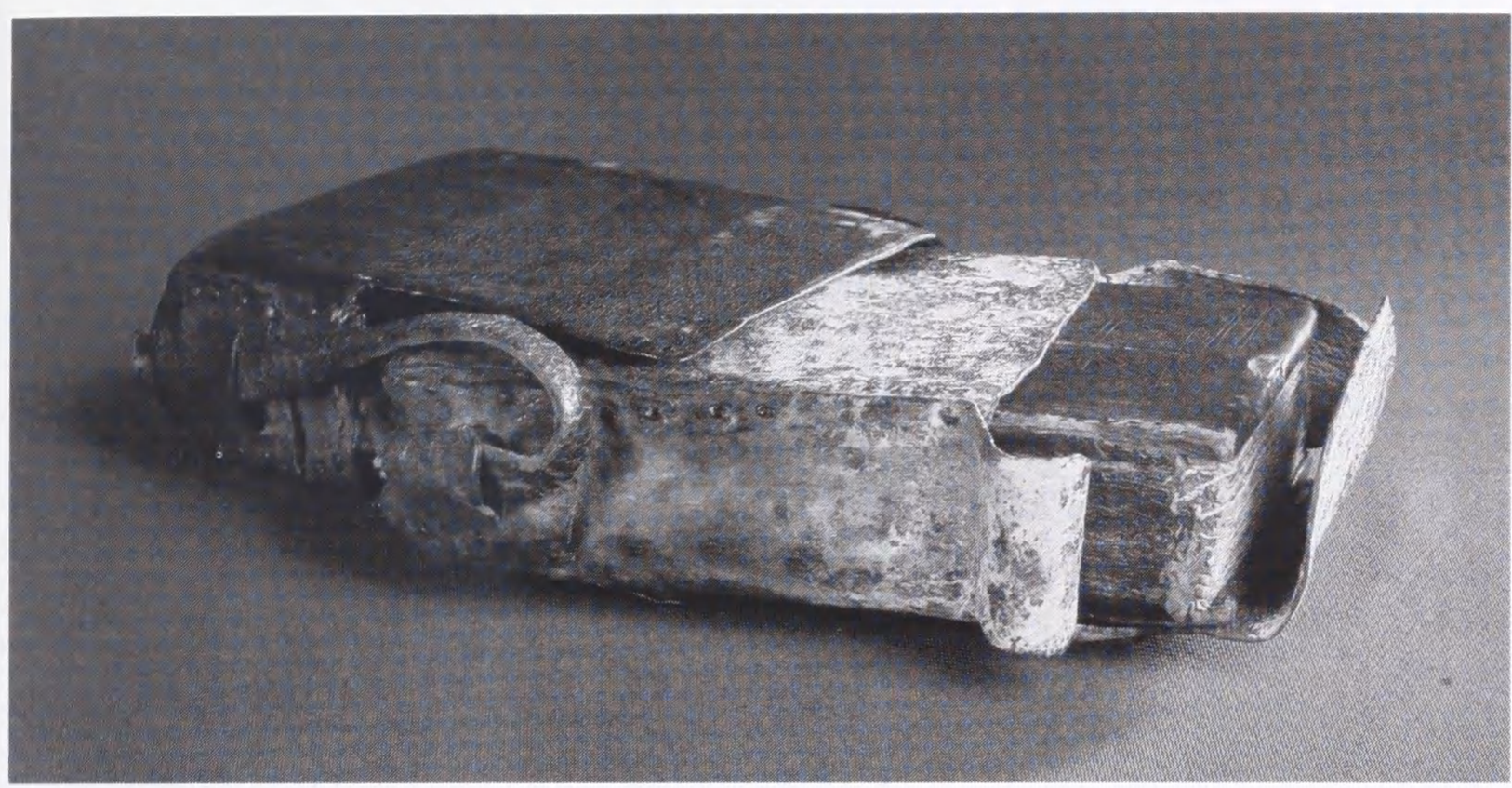

Fig. 7. Pergamenthandskrift i traditionel indbinding fra det 1800-tallets Etiopien anbragt $i$ en ladertaske. Den ubeskyttede ryg kan lige anes til hojre ved taskens åbning (Det Kongelige Bibliotek).

omviklende remme og stropper af forskelligt materiale. Dækpladerne af træ fik undertiden udsmykninger med ben og læder. Mange af træpladerne blev helt dækket af læder med mere eller mindre komplicerede prægede ornamenter.

Med inspiration fra de koptiske bøger, bl.a. fra Etiopien, udvikledes en indbinding, kodex, som har holdt sig op til 1700-tallet, hvor den europæiske indbindingsmetode erstattede den traditionelle islamiske indbinding. Pergamentarkene blev foldet til bundter, på almindeligvis fire sider, og beskrevet. Disse sider blev dernæst lagt sammen med andre ark i den rigtige rækkefølge for til sidst at blive syet (hæftet) sammen i ryggen. Den etiopiske hæftning består af kædesting, der så at sige binder arkene (hver med fire sider) sammen med en løkke (luftmaske) ned om den fastgjorte tråd på det forrige ark. I begyndelse var ryggen uden beskyttende dække, således at man kunne se hæftningen.

Dette kunne medføre et hårdt slid på hæftningen, der derfor let kunne få siderne i bogen til at falde ud. Derfor begyndte man at lime et rygdække direkte på ryggens hæftning. Dette dække var som regel af læder. I 11-1200-tallet ændredes bindenes form og den typiske islamiske bog med en beskyttende flap, der bøjes hen over bindets åbning modsat ryggen, udvikledes. Herom senere.

\section{Mundtlig og nedskreven overlevering}

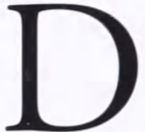
et menes at personer, der hørte Muhammeds gengivelser af sine åbenbaringer, Koranen (Qur'an oplæsning), nedskrev dele eller det hele af disse, for at kunne huske dem. Traditionelt angiver muslimske lærde at åbenbaringerne blev nedskrevet på forhåndenværende materiale såsom ben, palmeblade og potteskår. Efter Muhammeds død i 632 blev de bevaret dels gennem hukommelsen og dels gennem de nedskrevne tekstdele. Senere nedskrev man dem på pergament. Da Koranen anses for at være 
en guddommelig tekst, var og er det vigtig for en muslim at kunne recitere den efter hukommelsen. Dette betyder at Koranen både overleveredes mundtlig og skriftlig fra den tidligste tid. Mange andre islamiske tekster blev ligeledes bevaret for eftertiden gennem hukommelsen fordi den mundtlige overlevering af alle tekster havde en høj status.

For at Koranen og andre islamiske tekster kunne videregives uden fejl ved nedskrivningen udvikledes allerede tidligt $\mathrm{i}$ 600-tallet en autorisationsmetode, som senere også blev benyttet ved kopiering af allerede eksisterende tekster. En forfatter læste sit værk op for en kreds af mennesker, der så nedskrev denne på pergament eller papir. Når oplæsningen var endt, skulle kopisterne så læse deres nedskrevne tekst op for forfatteren, så han kunne korrigere og godkende nedskrivningen. Senere når en kopiering af en allerede nedskreven tekst skulle finde sted, måtte denne kopiering ligeledes godkendes af lærde som en korrekt afskrivning. Dette sikrede en meget høj kvalitet af tekstoverleveringer, således at kun ganske få afvigelser opstod i de forskellige afskrifter.

Da det tidlige arabiske skrift ikke var så udviklet, som det er i dag, kunne der opstå misforståelser ved nedskrivningen af tekster. I disse tidlige skrifter blev der f.eks. ikke altid angivet korte vokaler, og konsonanter med lignende former blev kun en gang imellem angivet med særlige markeringer. Dette fremmede desuden den mundtlige overlevering, men varianter opstod dog alligevel. For Koranens tekst er det vigtigt at teksten er en og den samme, men små varianter, der ikke ændrer meningen, er blevet tilladt, således at man i Indien og Vest Afrika kan se sådanne varianter af Koran-tekster. For an- dre bøgers vedkommende ser man også varianter, og mange trykte udgaver af ældre tekster er derfor blevet afstemt med forskellige håndskrifter, hvis der eksisterer mere end et håndskrift af en given tekst.

Som nævnt i indledningen udviklede man ikke i den islamiske verden et bogtryk, der kunne udbrede teksterne i en billig form, som man kan se i Kina fra den sene del af 700-tallet og i Vesten fra 1400-tallet. Dette skyldes dels den arabiske skrift der med sine bestemte sammenføjninger af de enkelte bogstaver gør det mere arbejdskrævende at overføre f.eks. til en træblok, og dels at den mundtlige tradition var meget stærk. Af disse grunde

valgte man i den islamiske verden at skrive teksterne i hånden. Selvom håndskrifter er relativt kostbare at fremstille, har man haft mange bøger i den islamiske kulturkreds til alle tider. Den første trykte arabiske bog med løse typer kom fra Italien i 1514, men der skulle gå en del tid før en bog blev trykt med løse typer i selve den arabiske verden. Det skete i 1706, men det varede alligevel et århundrede før det blev mere almindeligt at trykke med løse typer som i Vesten. I begyndelse fik den litografiske trykteknik dog en stor udbredelse, da bogtrykkeren kunne gengive et håndskrift side for side og bevare en smukke kalligrafiske udformning, men senere i den tidlige del af 1900-tallet gled denne teknik mere eller mindre ud af brug.

\section{Format}

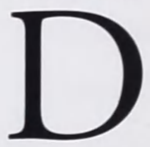

e første Korantekster var skrevet i et vertikalt format, dvs. at højden af arkene og dækpladerne var hø jere end bredden, en indflydelse man fik fra den kristne og jødiske tradition. Man allerede i 700-tallet ændrede dette sig til et horisontalt format - et tværformat - hvor 


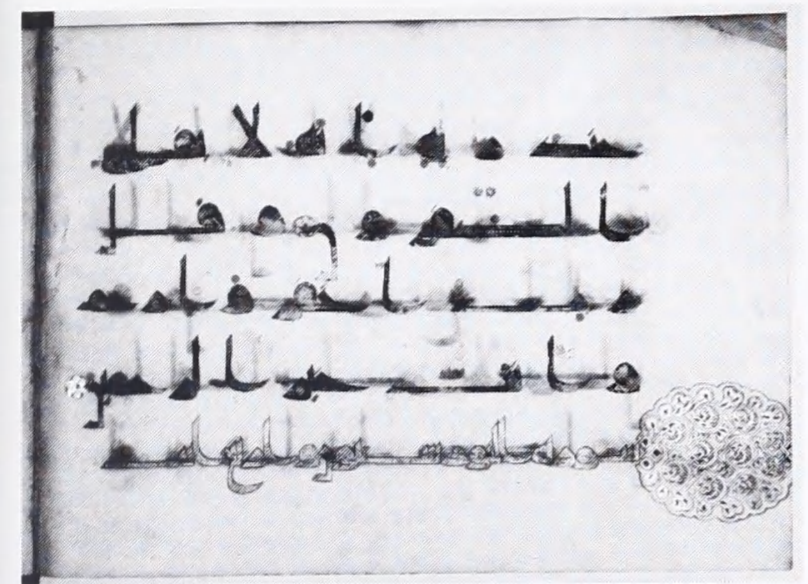

Fig. 8. Koran i kufi-skrift på pergament, 10. Arh.; illumineret overskrift til sûra 24, alNûr (Lyset) (Det Kongelige Bibliotek).

bredden var større end højden. Dette format holdt sig ind i 1000-tallet, hvor det vertikale format igen blev standard. Man anvendte næsten ikke rulleformatet som til gengæld var almindeligt i den jødiske kultur og i de tidlige kristne skrifter. Rulleformater blev kun taget i brug ved særlige lejligheder og man kender det mest fra det osmanniske rige (1284-1922), hvor officielle dokumenter, især udnævnelser, blev skrevet på lange papirbaner, der blev rullet sammen.

Ændringen fra det vertikale format til tværformatet i 700-tallet faldt sammen med at man begyndte at skrive arabisk med en skriftstil, der har lange ret brede strøg og med bogstaverne i en let kantet udformning. Skriften kaldes Kufi efter bynavnet al-Kûfah i det sydlige Irak, hvor man formodentlig først anvendte denne stilart. Byen al-Kûfah havde da udviklet sig til et islamisk intellektuelt center. Teksterne var alle skrevet på pergament, da papir først blev introduceret til den østlige del af islamiske verden i den sene del af 700-tallet. Kufi-stilen er også kendetegnet ved dekorative elementer som dels er diakritiske mærker, vokal anmærkninger og dels geometriske ornamenter. Disse markeringer og ornamenter er ofte udført i farver, hvor bogstaverne er i sort blæk.

Skriften i denne stil fremtræder som en monumental skrift, der kan minde om inskriptioner på hellige bygninger. Der er da også en del forskere, der er af den mening, at Kufi-stilen netop er inspireret af sådanne inskriptioner.

I 900-tallet begyndte en del kalligrafer at anvende papir som skrivemateriale for hellige bøger. Samtidig havde der udviklet sig en mere rund Kufi-stil kaldet den kursive stil. Denne stilart lagde vægt på højden i skriften og ikke som tidligere på længden. Bogstaverne blev nu mere markeret i aflange strøg og med tydelig kontrast mellem tykke og tynde strøg. Dette var formodentlig grunden til at man begyndte at anvende det vertikale format $\mathrm{i}$ skrivematerialet.

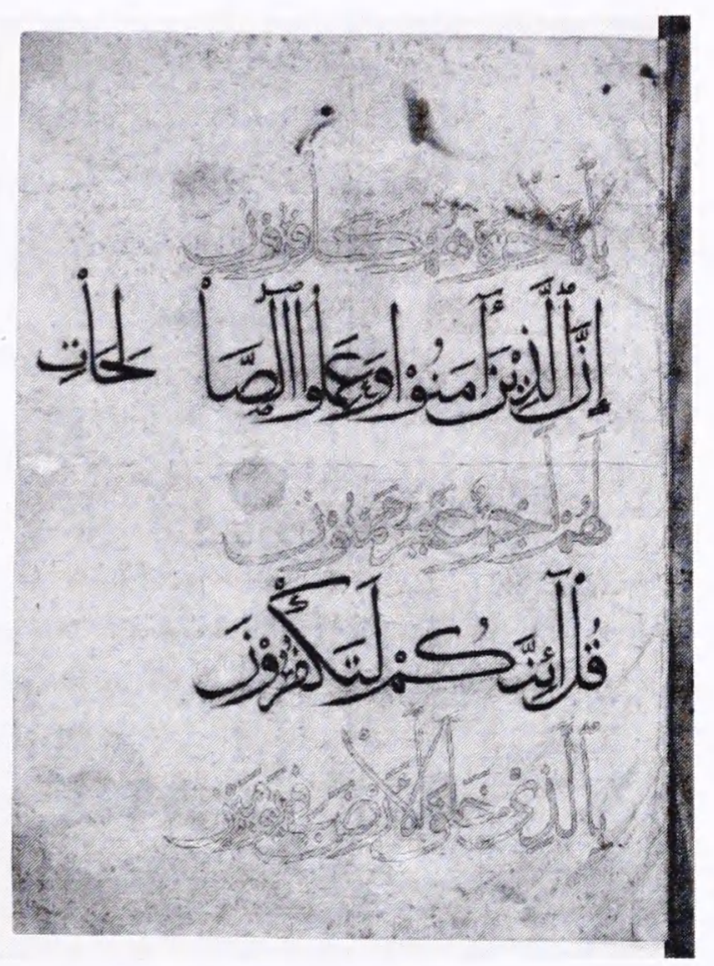

Fig. 9. Koranfragment skrevet $i$

thuluth/muhaqqaq-skrif, ca. 1306-10 (Det Kongelige Bibliotek). 
Dog fortsatte en del kalligrafer med at benytte tværformatet til hellige skrifter i hele den islamiske kulturkreds ind i 1000-tallet og i den vestlige del af den islamiske verden helt op til 1300-tallet Det vertikale format blev gradvis det mest almindelige og har holdt sin popularitet helt til i dag. Dette skyldes måske også at det vertikale format er lettere at håndtere end tværformatet, der kræver mere understøttelse ved læsning.

\section{Materialer}

\section{Papyrus}

$\mathrm{P}$ apyrus var udbredt som skrivemateriale i Middelhavsområdet og Mellemøsten på det tidspunkt, hvor islam opstod. Der er da også fundet arabisk papyrus, der kan dateres til det sene 600-tal og tidlig700-tal i Egypten. Den overvejende del af disse papyrustekster er enkelte ark. De er dokumenter med administrations- og beskatningstekster og privat- eller handelsbreve Der er kun fundet ganske fă bøger med papyrusblade og den der er tidligst dateret, er fra år 844 . Allerede i 900-tallet er både produktionen og kvaliteten af papyrus faldet drastisk. Papiret har helt klart udkonkurreret papyrus på den tid.

\section{Pergament}

$\mathrm{P}$ ergament er skind, der er bearbejdet for at gøre det velegnet til nedskrivning af tekster. I den islamiske verden benyttede man sig ofte af gede- og fåreskind men skind af vilde dyr, f.eks. gazelleskind, blev ligeledes anvendt. En del af perga-mentarkene var af meget høj kvalitet, hvad gjorde dem ekstra efterspurgte til udførelsen af pragtkoraner. I særlige tilfælde kunne man desuden farve dem dybt blå og skrive teksten med guldblæk.
Anvendelsen af pergament forsvandt gradvis fra 900-tallet. til 1300-tallet, og i dette tidsrum blev det kun anvendt til kopiering af Koranen og få andre religiøse tekster.

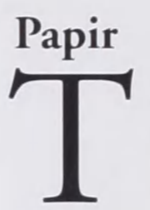

raditionelt menes det at viden om papirfremstilling kom til arabernes kendskab efter tilfangetagelsen af nogle kinesiske papirmagere i forbindelse med slaget mod kinesiske styrker ved Thalas i Centralasien i år 751. Efter denne tid opstod der i Samarkand en papirfremstilling, der hurtigt bredte sig til Bagdad, og i 800-tallet fandtes papirfremstillingen i Kairo. I den sene del af 900-tallet var produktionen af papir etableret i hele Nordafrika, og i år 1056 blev den første papirmølle etableret i Spanien. Papir fremstillet i Samarkand blev dog i mange årtier anset for at være af fornemmeste kvalitet. Senere var papir fra Damaskus også yndet af skribenter, og en driftig eksport til det kristne Europa var ligeledes stor. Fra 1300-tallet synes strømmen af papir at vende fra Europa til den vestlige islamiske verden. De første, der etablerede en stor givtig eksport til Mellemøsten, var italienere, og senere kom også fransk papir til den islamiske verden.

Papir fremstillet i Kina var en blanding af plantefibre, undertiden forbedret med tekstilfibre. Det arabiske papir havde hør og hamp som hovedbestanddelene. Hør kom til papirmøllen i form af tøjklude og hamp i form af rebstykker. Dette sikrede en høj kvalitet af papiret, da papir fremstillet af rå plantefibre kunne være af ringere standard. Ligesom i Kina blev der anvendt en ramme med et netværk af ribber til fremstillingen af papirarkene. Rammen blev dyppet i papir massen og overskydende masse og vand dryp- 


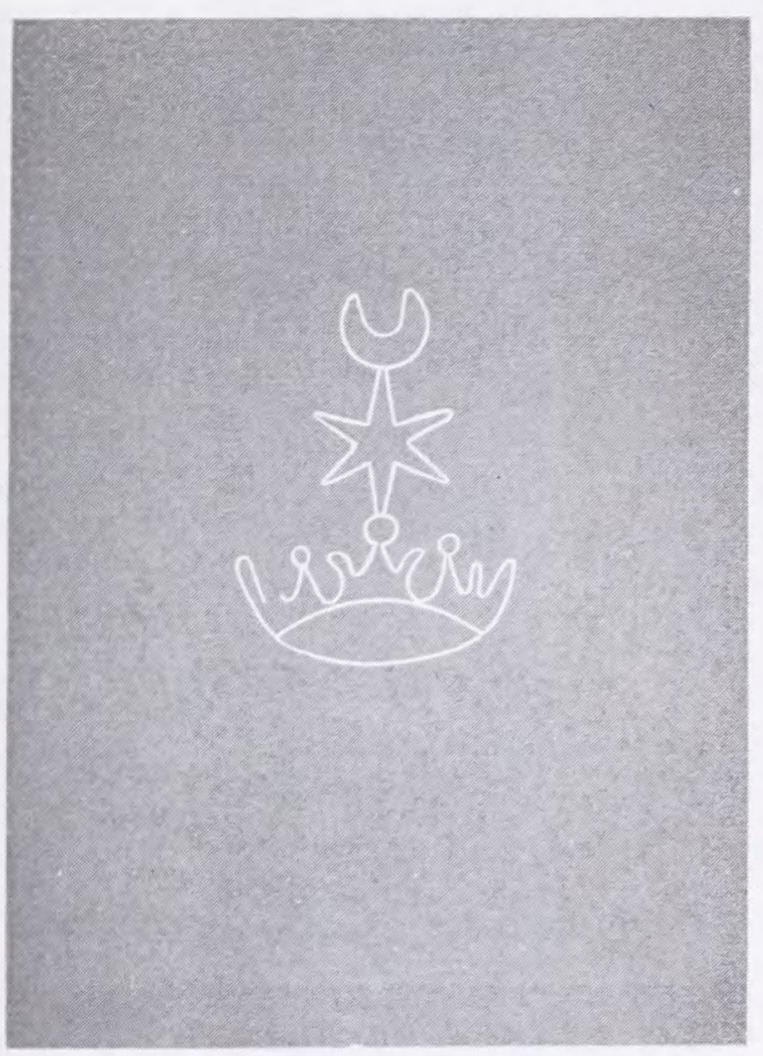

Fig. 10. Vandmarke på europaisk papir fra et tyrkisk handskrevet dokument fra $1600-$ tallet (Det Kongelige Bibliotek).

pede af ved en let rystning og vipning af rammen. Ribberne i rammen efterlader sædvanligvis mærker som

lange streger, men i en del islamisk papir er disse ikke synlige. Det må have betydet at ribberne i rammen har været beklædt med en form af et væv, som udvisker vandmærkerne.

Papirark fremstilledes i forskellige størrelser, og der synes ikke at have været en egentlig standard. De mest almindelige størrelser før den endelige tilskæring ved indbindng har været fra ca. $360 \times 270 \mathrm{~mm}$ til $850 \times 580 \mathrm{~mm}$.

I den traditionelle islamiske papirfremstilling synes der ikke at have været anvendt vandmærker, som det kan ses i Kina og senere i Europa. En stor del af det papir der eksporteredes fra Europa havde vandmærker, og de europæiske papirmøller forsøgte for det meste at fremstille vandmærker, der ikke kunne støde den islamiske tro. Således ser man ofte halvmåner, stjerne og kroner.

\section{Skrivepapir, farvet papir og dekoreret papir}

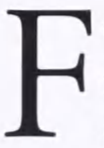

or at kunne skrive med blæk eller tusch på nyfremstillet papir må det først bearbejdes. Rå papir vil opsuge blæk og tusch i en uens hastighed og efterlade stregerne i bogstaverne i uklare linier. Derfor tilføjede den islamiske papirfremstiller eller skribent et overlag gennem at glitte papiret dvs. at gnide en mineralsk og vegetabilsk substans ned i papirets overflade, så streger tegnet på denne overflade ville stå frem i skarpe og klare linier. Det havde dog den lille ulempe at man skulle passe på ikke at røre den nyskrevne tekst før blækket var helt tørt. Man kan i en del håndskrifter se at blækket nogle steder har været udsat for udtværing.

Mange islamiske kalligrafer holdt meget af at skrive deres kunstnerisk udformede tekster på farvet papir. En del kalligrafiske bøger har forskellige farvede sider ofte med teksten i fint indrammede tekstruder. Farvning af papiret kunne ske ved at farve selve papiret eller ved at tilføje et farvemiddel i glitningsprocessen. Der findes mange farver såsom gul, blå, grøn og rød, men rød synes i forskellige nuancer at have været meget populær. Det skyldes højst sandsynlig at rød blev forbundet med fest, glæde og humanitet. Blå stod i Syrien og Egypten for sorg, og dødsdomme var på disse steder skrevet på blåt papir, mens i Persien ser man f.eks. digtsamlinger skrevet på blåt papir. En gang imellem ser man kalligrafiske bøger med forskellige farver side for side. 


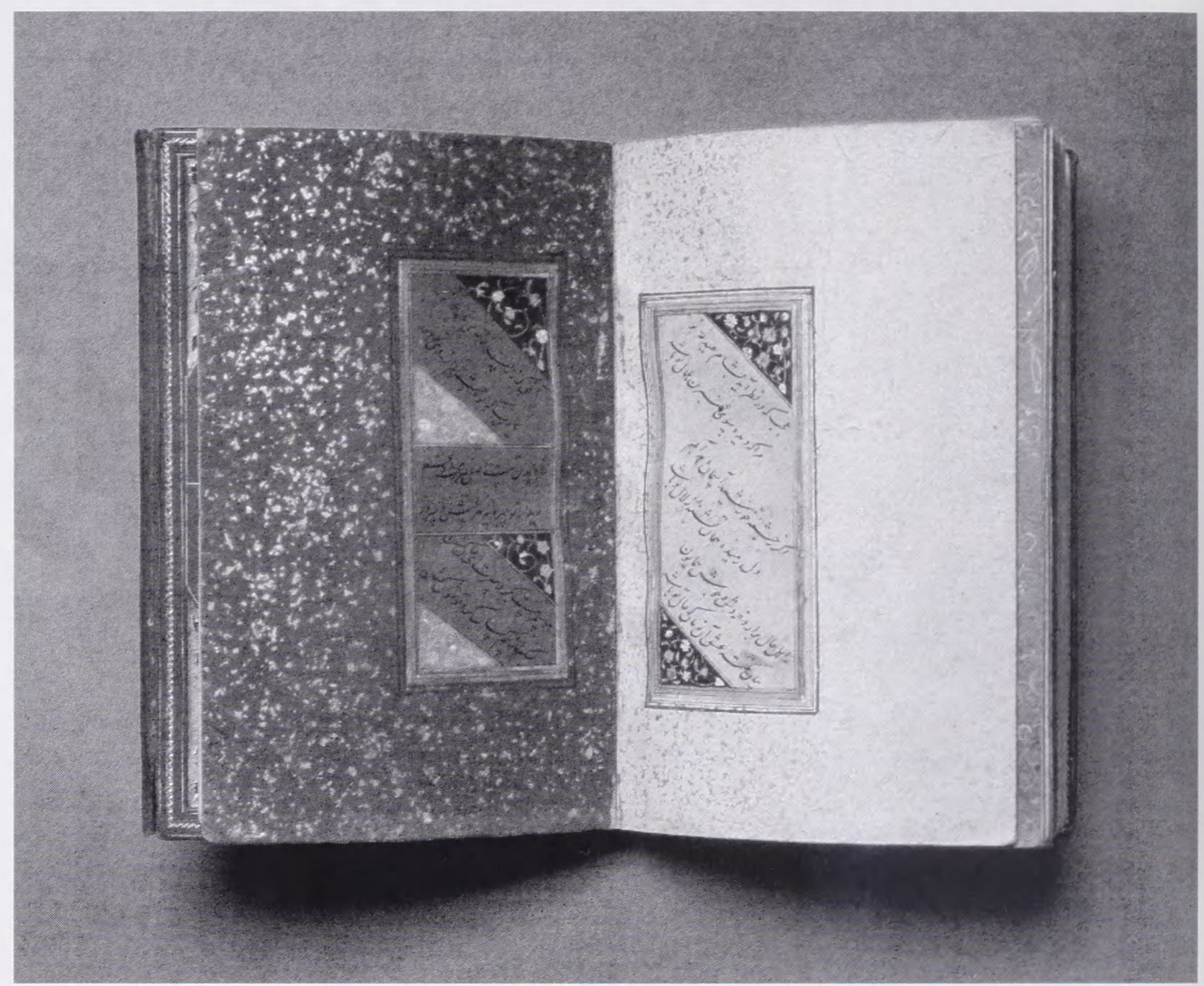

Fig. 11. To af sider af en samling af digte skrevet med en fin nasta'lî-skrift på forskelligfarvet papir 15-1600-tallet (Det Kongelige Bibliotek).

For at gøre kalligrafien mere fornem og attraktiv dekorerede man også selve papiret, og fra 1500-tallet blev det meget populært - især blandt persiske kalligrafer. Dekorationerne, der alle var af nonfigurativ art, kunne være i margen af siderne eller ses spredt ud over hele siden. De kunne være malet på siderne eller strøget ud over siderne med guld, sølv eller andre farver.

Fra den tidlige del af 1500 tallet anvendte man i Persien marmoreret papir, og denne type af papir blev introduceret til Europa i slutningen af samme århundrede. Marmoreret papir blev benyt- tet som forblade i de indbundne bøger, da selve marmoreringens farver og mønstre ikke egnede sig til skrift. Man anvendte også dette papir til det ydre bogbind på mange islamiske bøger. Bogbindere benyttede ligeledes papir spættet med guld, sølv og andre farver som forblade i de indbundne bøger. Fremstillingen af marmoreret papir blev en værdsat produktion i Tyrkiet, og tyrkiske værksteder fremstiller stadigvæk dette papir den dag i dag i høj kvalitet. 


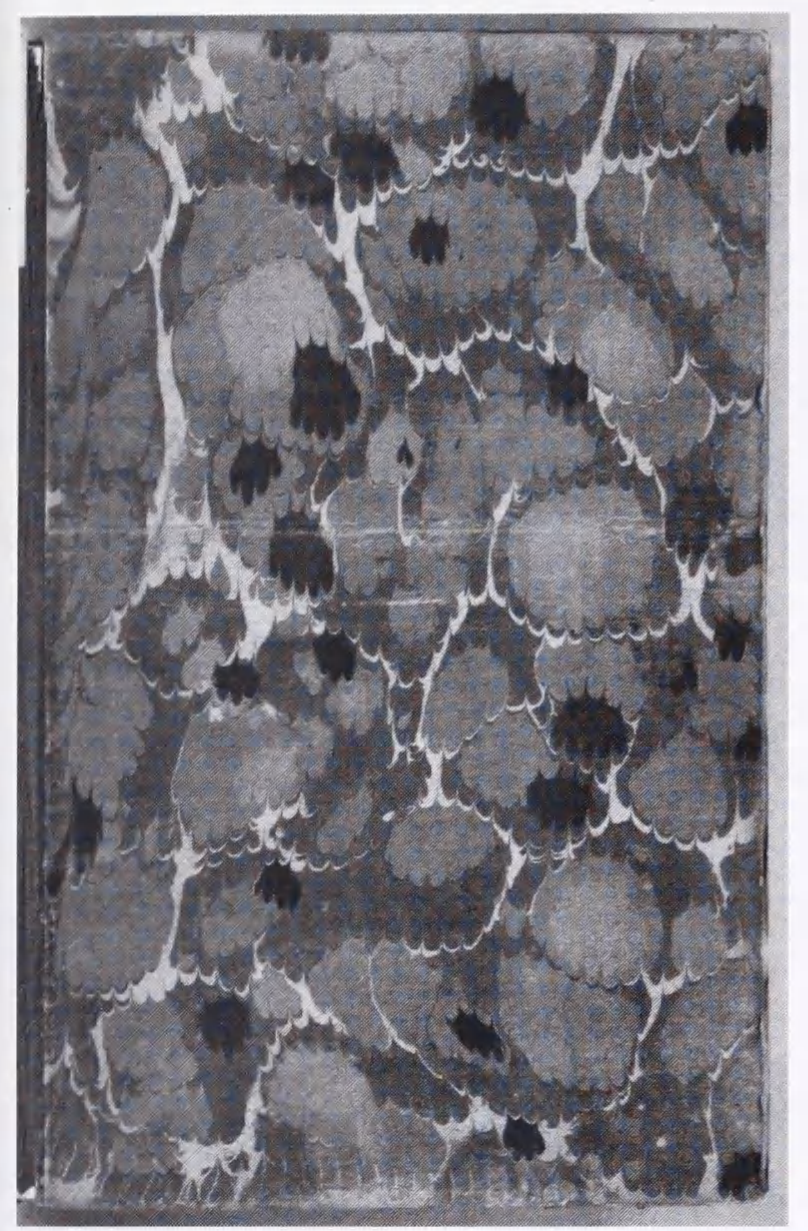

Fig. 12 Marmoreret papir fra et indbundet persisk håndskrift. 1607 (Det Kongelige Bibliotek).

\section{Indbinding}

口r selve indbindingen bliver papir-

arkene foldet sammen, således at de udgør to, fire, otte eller seksten sider alt efter hvor stor man ønsker siden. Hvis der er behov for et ulige antal sider kan man lime en side til et ark.

Arkene lægges oven på hinanden og hæftes (syes) sammen med tråd ved rygfolden til en bogblok med alle siderne samlet. De tråde der blev anvendt til hæftningen var enten af hør eller silke. For at sikre at alle arkene lægges i den rigtige rækkefølge ligesom siderne i selve arket har man angivet på et folie (for og bagside af et blad) det første ord eller stavelse på næ- ste side, kaldet kustode. I de traditionelle islamiske bøger anvendtes den koptiske eller etiopiske hæftning, der en slags kædesyning. På ryggen af bogblokken limes et stykke læder eller papir for at beskytte hæftetrådene mod slid. Efter endt hæftning og påsætning af rygbeskyttel-sen skæres bogblokken til foroven, nederst og modsat hæftningen, så man får en fint afpasset enhed.

Kapitælbånd bliver syet på øverste og nederste del af ryggen af bogblokken for at skåne ryggens ender mod slid. Båndene er ofte med to farvede tråde, der danner par såsom rød-hvid, rød-gul og grøn-lyserød. En del bogbind mangler en beskyt-telseskerne, gerne et tyndt læderstykke, ved enden af ryggen, således at selve syningen af kapitælbåndet kommer til at skade papiret i bogblokken efter en del brug.

Mange kalligrafer ville sikre deres egne værker en bedre levetid, så mange af dem indbandt selv deres bøger. Nogle af dem blev så kendte på deres fine indbindinger, at de supplerede deres indkomst med også at indbinde for andre. Sådanne indbindinger var kostbare, så boghåndværket var blandt andet på den baggrund anset for at være et velset virke i den islamiske verden.

Det typiske islamiske bogbind har en ekstra flap på venstre del af bindet. Denne flap er formet, der ligner en konvoluts bagklap, og den foldes ind over bogblokkens forsiden og lægges ind under øverste del af bindets forside.

Således fremtræder det islamiske bogbind som en slags kapsel, hvor kun øverste og nederste del af bogblokken er synlig. Bindet med flappen er lidt større end bogblokken ligesom hos det europæiske bogbind, så blokken bliver beskyttet 


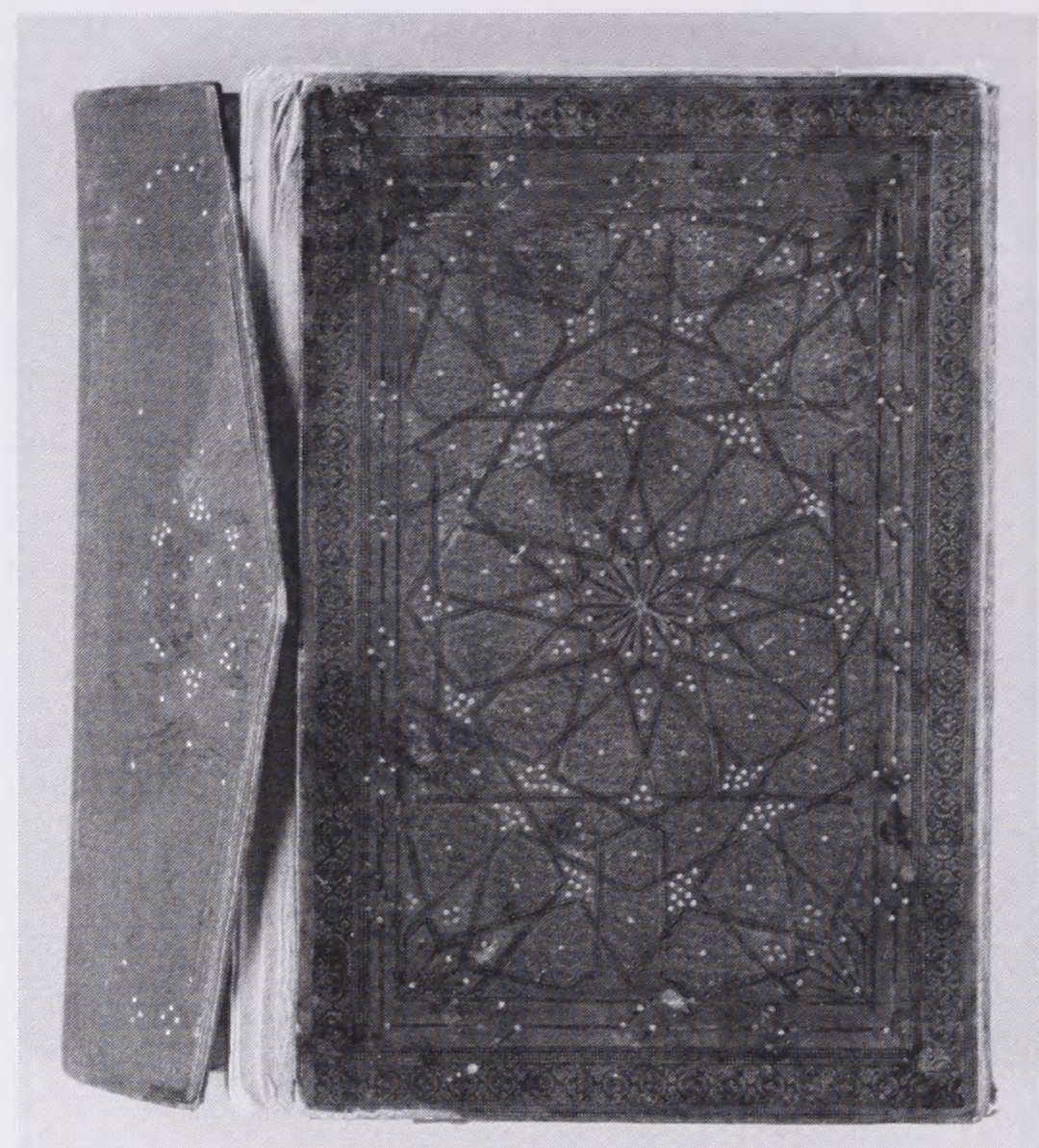

Fig. 13. Arabisk bogbind med to religiose tekster af Abî l-Farag Ibn al-Gawzî (d. 1201). Det er købt i Konstantinopel i 1761 af F. C. von Haven, der deltog $i$ Carsten Niebuhrs ekspedition til Arabien 1761-1767 (Det Kongelige Bibliotek).

mod unødig slid. Det islamiske bogbind bliver limet til bogblokken ved ryggen med en vedhæftet række af flapper. For yderligere at forstærke sammenføjningen af bind og blok limes der ofte et stykke papir eller læder over det indre af bindet (forsats) og henover samlingen ved ryggen med flaphængslerne for derved at udgøre forbladet; for papirs vedkommende anvendtes gerne de tidligere nævnte marmorerede eller spættede papirstykker.

Da det islamiske bogbind bliver limet til bogblokken, er der en stor fare for at bind og bogblok let adskilles, således at både titelbladet og sidste blad i bogen med kolofonen enten bliver beskadiget eller går helt til. Derved mistes vigtige oplysninger om bogens forfatter og titel fra første blad i bogen og om afskriften af teksten i kolofonen.
Bogbindets ydre sider er meget ofte dekoreret på forskellige måder med geometriske mønstre eller stiliserede planteornamenter. Hvis bindet er af læder ornamenterede man det gerne ved prægning og tilføjede undertiden guldbemaling. Indlæg med andre materialer såsom ben ses også. Papirbind har som regel en udsmykning, der er indfarvet eller påtrykt. Her er det igen geometriske mønstre eller planteornamenter, der er de mest udprægede. Bindene havde desuden ofte en farvet baggrund, såsom blå, rød, grøn, gul , sort, hvid og brun. Læderbindene kunne også været farvet, dog ser man oftest sort, brun og gulbrun anvendt.

De tidlige Korantekster på pergament blev beskyttet med træplader eller af papyrusplader, som blev fremstillet af flere sammenlimede papyrusblade. Senere 
Fig. 14. På dette bind ses rakken af bindets rygflapper tydeligt, da bogen ikke har fäet påsat et forblad. Verket er en Koran fra 1600-tallet (Det Kongelige Bibliotek).

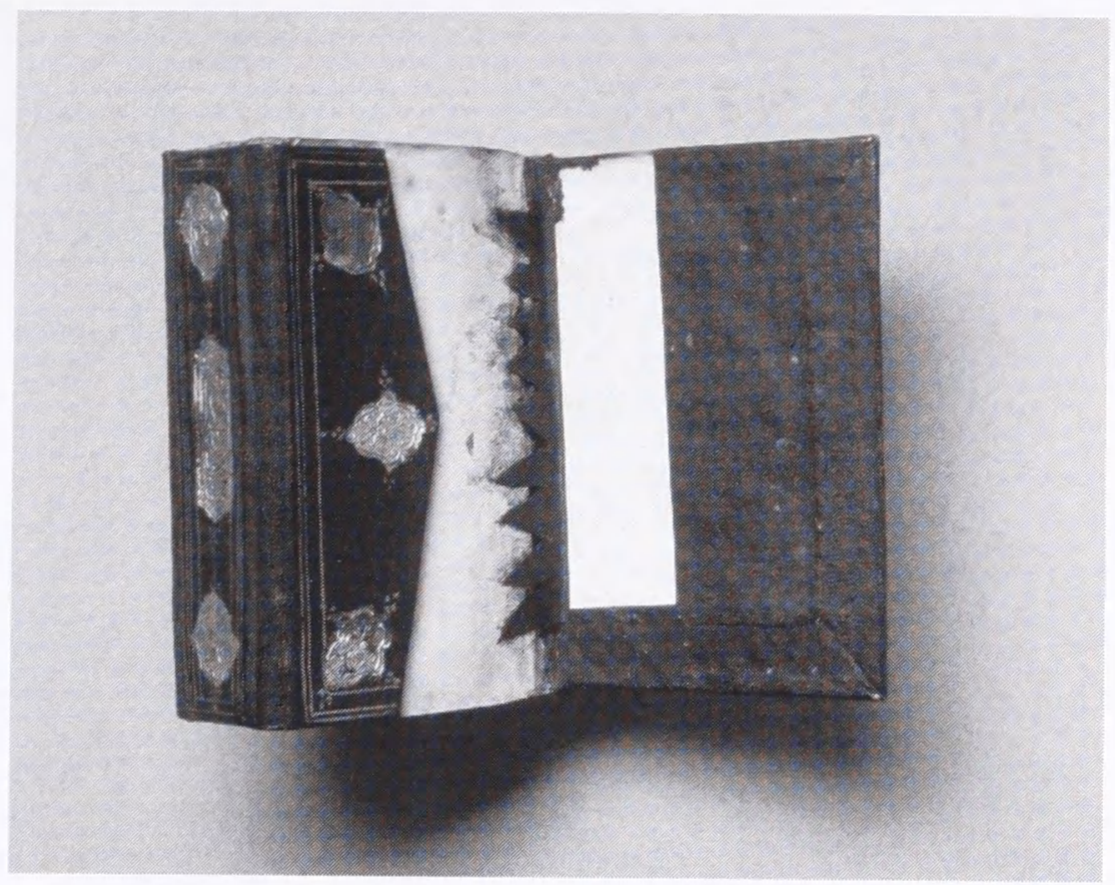

da papiret blev det almindeligste skrivemateriale kom bindet til at bestå af skind, af sammenlimede papirstykker eller i den tidlige del også af de sammenlimede papyrusblade. Tekstil kunne også anvendes som det ydre lag på et bind af sammenklæbet papir, men det forekom ikke så hyppigt. De tidlige dækplader af træ og

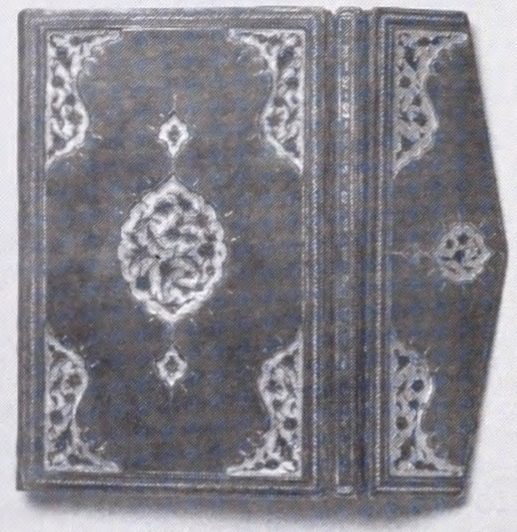

Fig. 15. Udsmykket bind på persisk bog med kalligrafi, 1600-tallet (Det Kongelige Bibliotek). papyrus havde ofte udskåret eller indlagte ornamenter. Det kunne være enkle medaljonornamenter i centrum af dækpladen eller en mere fuld ornamentik, hvor hjørnerne på pladen ligeledes havde mønstre. Udsmykningen kan være forskellige fra øvre til nedre dækplade. Mange bind har et ganske enkel centralplaceret ornament, men fra 1100-tallet kan man undertiden se ornamentikken brede sig ud på hele bindets flade. Man kan ikke dekorere en Koran med billeder af landskaber, dyr, mennesker og lig-nende, men man kan ornamentere en Koran med geometriske og epigrafiske mønstre og med plantemønstre. Dette gælder både det indre, selve teksten, og det ydre, bindet.

Andre dekorationer, der dækker hele bindets flade, ligger gerne i rammer med den indre ornamentik i kunstfærdige geometriske mønstre (se fig. 13). Undertiden kan inskriptioner indlemmes i dekorationen. Op til 1500-tallet benyttede man et stempel for hver del af dekorationen, men i 1500-tallet ser man store stempler, der kan dekorere en hel bindside ad gan- 


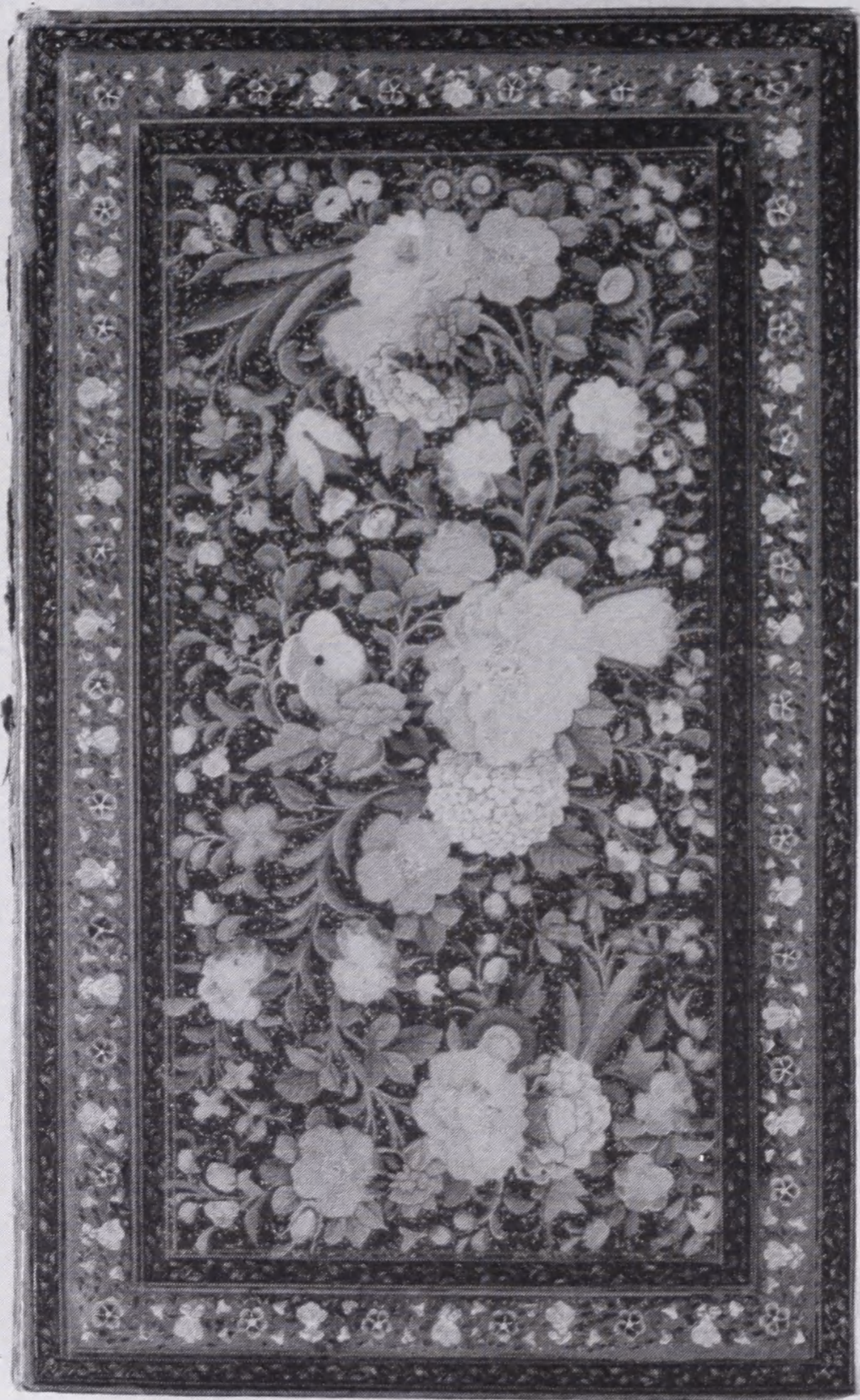

Fig. 16. Persisk lakbind fra ca. 1850 (Det Kongelige Bibliotek).

gen. Denne metode var meget tidsbesparende for bogbinderen.

I det persiske og indiske område begyndte man at dekorere bogbind af papmaché dækket af lak (egentlig fernis af harpiks) i 1400-tallet.

På den grundede papmachéflade malede man så dekorationer som blev afsluttet af et lag gennemsigtigt lak, hvorved dekorationer i de forskellige farver stod tydeligt frem under den skinnende overflade. Bind dekoreret med denne tek- nik havde først planteornamenter og geometriske mønstre, men fra 1500-tallet kom også figurative dekorationer på bindene. Da det er meget almindeligt at dekorere de to indersider af det islamiske bindet (forsatsen) hvad enten de er beklædt med læder eller papir, havde mange af de persiske lakbind yderst en nonfigurativ dekoration og en figurativ illustration på forsatsen af bindet, også i lak. 


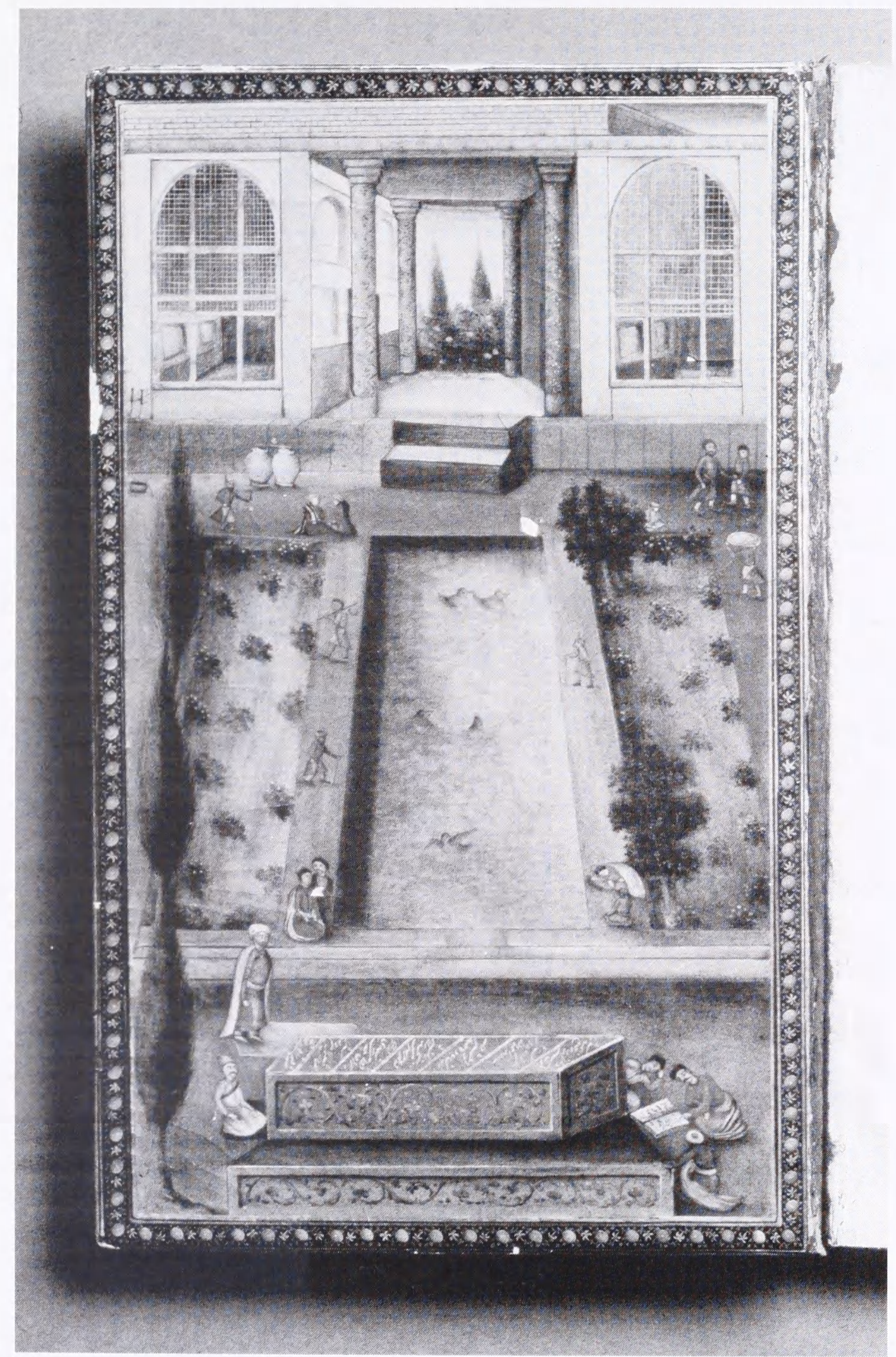

Fig. 17. Indersiden af et lakbind om håndskriftet, Dîwân-i Hâfiz, de samlede digte af Shams al-Dîn Muhammad Hâfiz (ca. 1325-1388 e.Kr.), dateret 1219 H. (1804 evt.). Hâfiz, der står nederst til venstre, er en af persisk poesis storste digtere, tilbragte det meste af sit liv i Shiraz (Det Kongelige Bibliotek). 


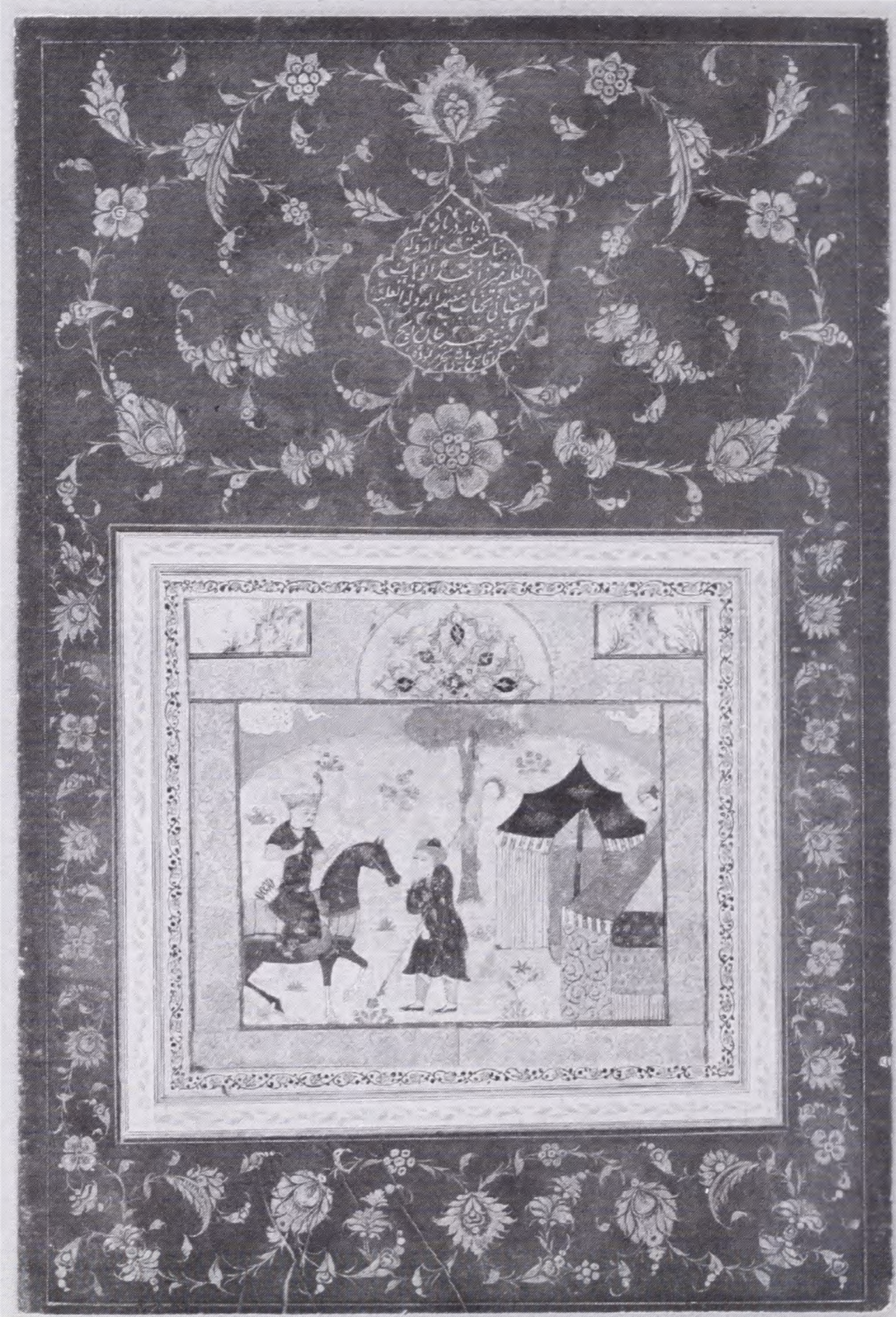

Fig. 18. Miniature med et motiv fra den episke fortelling 'Khamsa fra Nizami' Nord Iran ca. 1480 (Det Kongelige Bibliotek).

Illustrationer og miniaturebilleder

T den islamiske verden har man tolket en sentens i Koranen som et forbud mod afbildning af levende organismer meget alvorligt, men man ser dog alligevel mange bøger udfyldt med billeder af mennesker og dyr. Man har relativt tidligt kunnet illustrere videnskabelige bøger med døde genstande som nåle, knive og beholdere i medicinske bøger eller geometriske 
figurer i matematiske bøger. Dog har man skrevne kilder der også beretter om illustrerede episke fortællinger og historiske bøger i den vestlige del af den islamiske kulturkreds allerede fra 700-tallet. Nogle få eksempler på illustrerede bøger fremstillet i f.eks. Egypten haves fra 1000-tallet.

Billedillustrationer blev mere almindelige fra 1200-tallet og mange blev fremstillet i Syrien og Irak, men en del kendes ligeledes fra Nordafrika og fra de muslimske dynastier i Spanien (7561492).

Senere udvikledes en overdådig billedtradition i Iran fra 1300- til 1600tallet, hvor både helsides illustratio-ner og mindre billeder indført i teksten kan ses.
I det indiske område kendes ligeledes fine illustrerede bøger fra 1500 til 1800-tallet. Især Mogul-dynastierne i det nordlige Indien (1519-1806) er kendte for deres støtte til udviklingen af fine dekorative bogillustrationer. Nogle værker bestod udelukkende af miniaturebilleder, og blandt disse bøger findes portrætsamlinger af Mogulfyrsterne og deres nærmeste familie. Også i den tyrkiske del af det osmanniske rige ses rigt illuminerede bøger. Illustrationer af hellige personer har altid været specielle, da man ikke har vist deres ansigter, men skjulte det med et hvidt klæde eller en lys plet. På den måde undgik illuminatoren af udføre en helligbrøde.

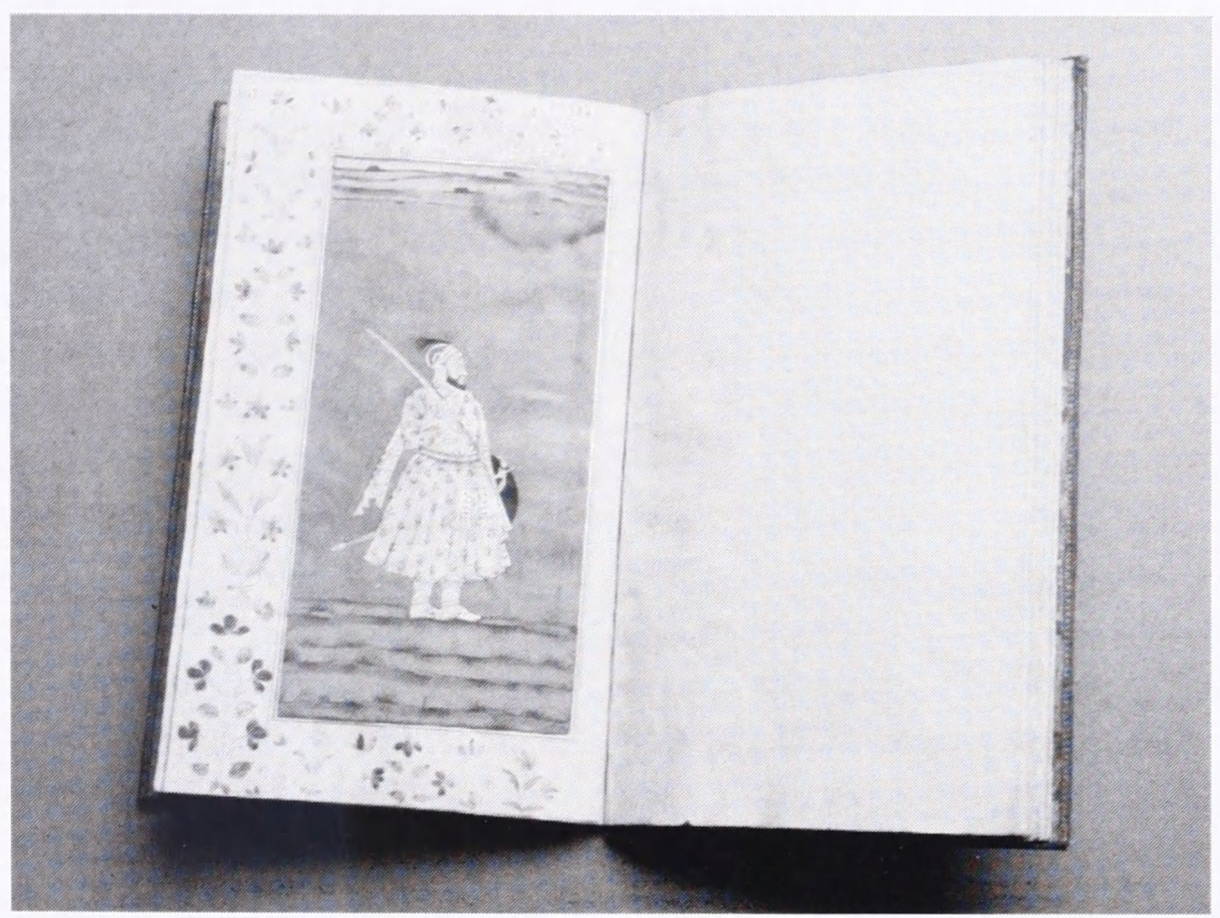

Fig. 19. Portret af en Mogulfyrste. Miniature fra et album med portretter af Mogul regenter i 1600-tallets Indien. Udfort i begyndelsen af 1700-tallet (Det Kongelige Bibliotek). 